\title{
A note on probiotics as an alternative for antibiotics in pigs
}

\author{
R. Link ${ }^{1}$, G. Kováč and J. Pistl \\ University of Veterinary Medicine \\ Komenského 73, 04181 Košice, Slovakia
}

(Received 13 September 2004; revised version 18 March 2005; accepted 4 August 2005)

\begin{abstract}
The aim of the present study was to evaluate the influence of the probiotic preparation BioPlus 2B, based on Bacillus licheniformis and Bacillus subtilis, on daily weight gains, feed conversion, general health, and stimulation of phagocytosis and mitogenesis of lymphocytes in pigs. Administration of probiotics significantly affected body weight and slightly affected mean daily gains $(6 \%)$ and feed conversion (12\%) of the experimental pigs. Also important was the protective effect against diarrhoea. These results indicate that probiotics based on representatives of the genus Bacillus could replace antibiotic growth stimulators.
\end{abstract}

KEY WORDS: pig, probiotics, antibiotics, performance

\section{INTRODUCTION}

Despite some advantages related to the use of antibiotics as stimulators of growth, some adverse effects related to such practices have also been noted and so gradual elimination of antibiotic stimulators has begun throughout the EU.

Great potential in prevention of the diarrhoeic syndrome of young of farm animals and subsequent improvement in animal growth has been attributed to probiotics. Recently, in addition to conventional probiotics based on the genera Lactobacillus and Bifidobacterium, preparations based on representatives of the genus Bacillus have come into the foreground. At present, 77 species belonging to the genus Bacillus are recognized, of which the following are used most frequently: coagulans, subtilis, clausii, cereus, toyoi. In the agricultural

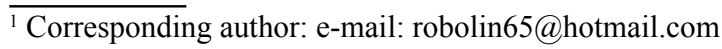


sector, Bacillus licheniformis has also been used to improve the health status of pigs and increase their weight gains. The advantage of spores as probiotics was demonstrated recently by La Ragione et al. (2001) who, after a single oral inoculum of $2.5 \times 10^{8}$ Bacillus subtilis to one-day-old chicks, observed that all symptoms of infection induced by previous inoculation of $E$. coli $078: \mathrm{K} 80$ were suppressed.

Our experiment focused on the influence of the preparation BioPlus 2B on weight gains, feed conversion, health and immunological parameters in pigs.

\section{MATERIAL AND METHODS}

\section{Animals}

Eighteen weaned piglets, cross-breds of Landrace $\times$ Large White, were included into the experiment. The pigs were divided into two groups: experimental E $(n=9)$ and control $C(n=9)$. They were weaned at the age of 35 days and after a week they were included into the experiment at the age of 42 days. The weanlings were fed starter mixed feed OŠ-02 (Tajba a.s., Čaňa, Slovakia) up to the $56^{\text {th }}$ day of age followed by complete pre-fattening mixed feed A1 (Tajba a.s., Čaňa, Slovakia) that was given up to the end of the experiment, i.e. to the age of 91 days (Table 1). Feed was given ad libitum and consumption was monitored daily.

TABLE 1

The content of nutrients and minerals in mixed feeds

\begin{tabular}{lcc}
\hline & Starter feed (OŠ-02) & Fattening feed (A1) \\
\hline $\mathrm{ME}, \mathrm{MJ} / \mathrm{kg}$ & 13.0 & 12.5 \\
Crude protein, \% & 18.6 & 17.0 \\
Ether extract, \% & 3.7 & 3.1 \\
Ash, \% & 6.7 & 5.8 \\
$\mathrm{NaCl}, \%$ & 0.9 & 1.0 \\
$\mathrm{CaCO}_{3}, \%$ & 1.6 & 1.1 \\
\hline
\end{tabular}

\section{Experimental design}

Pigs included into the experiment were kept in accordance with requirements for animal protection during experiments (Korim et al., 2003). The experiment lasted seven weeks, from the sixth week of the weanlings' life up to the age of three months. The experimental group $(n=9)$ was supplemented with the probiotic 
preparation BioPlus 2B (Christian Hansen's bio systems, Hørsholm, Denmark), added to the diet at a ratio of 1:1000, i.e. the number of spores of Bacillus licheniformis and Bacillus subtilis was $10^{9} / \mathrm{kg}$ feed. The diet of pigs from the control group was not supplemented with BioPlus 2B.Our investigations included observation of weight gains, feed intake, feed conversion, percentage proportion of diarrhoeic piglets and selected parameters of immunological profiles. Health was evaluated every day. The weanlings were weighed weekly and feed conversion was determined at the end of the experiment.

The occurrence of diarrhoea was assessed visually by the same person; diarrhoea was recognized if the faeces were pasty at least. The rate of diarrhoea was calculated according to the formula:

$$
\% \text { of diarrhoea cases }=\frac{\text { No. of diarrhoeal animals } \times \text { No. of days }}{\text { No. of animals in the group } \times \text { No. of days }} \times 100
$$

\section{Probiotic preparation}

BioPlus 2B is a probiotic preparation that contains equal numbers of Bacillus licheniformis and Bacillus subtilis, equal to $1.6 \times 10^{9} / \mathrm{g}$ preparation (Christian Hansen's bio systems, Hørsholm, Denmark).

\section{Sampling of blood}

Blood samples for determination of selected parameters for immunological examination were taken on day 0,28 and 49 of the trial. The blood was sampled from the eye sinus.

\section{Immunological tests}

A quantitative evaluation of the tetrazolium-reductase activity of phagocytes was carried out according to the method of Lokaj and Oburkova (1975) for the evaluation of metabolic activity (MA) of phagocytes during phagocytosis.

Leukocyte migration-inhibition assay (LMIA) was used to analyse the reaction capacity of lymphocytes to mitogenic activation and was carried out according to Bendixen et al. (1976).

\section{Statistical analysis}

Results were evaluated by Student's $t$ - test and analysis of variance. 


\section{RESULTS}

The experimental group already had achieved better weight gains in the second experimental week and this state continued up to the end of the experiment. Although the differences between groups in weight gains were insignificant, they were higher by $6 \%$ in the experimental group compared with the control (Table 2 ).

TABLE 2

Body weight and weight gains of pigs $(\mathrm{x} \pm \mathrm{SD})$

\begin{tabular}{|c|c|c|c|c|}
\hline \multirow{3}{*}{ Weight/week } & \multicolumn{4}{|c|}{ Groups } \\
\hline & \multicolumn{2}{|c|}{ weight, $\mathrm{kg}$} & \multicolumn{2}{|c|}{ Gains, $g /$ day } \\
\hline & E & $\mathrm{C}$ & E & $\mathrm{C}$ \\
\hline 0 & $13.1 \pm 1.8$ & $13.1 \pm 2.2$ & & \\
\hline 1 & $15.2 \pm 1.7$ & $15.2 \pm 2.4$ & $300 \pm 83$ & $300 \pm 108$ \\
\hline 2 & $18.4 \pm 2.8$ & $17.9 \pm 2.8$ & $457 \pm 177$ & $380 \pm 143$ \\
\hline 3 & $22.5 \pm 3.5$ & $21.4 \pm 3.0$ & $580 \pm 123$ & $500 \pm 41$ \\
\hline 4 & $28.2 \pm 4.3$ & $26.5 \pm 3.4$ & $810 \pm 117$ & $740 \pm 68$ \\
\hline 5 & $32.3 \pm 4.2$ & $30.5 \pm 4.9$ & $585 \pm 136$ & $560 \pm 276$ \\
\hline 6 & $37.9 \pm 4.8$ & $36.0 \pm 4.9$ & $810 \pm 108$ & $790 \pm 48$ \\
\hline 7 & $43.3 \pm 4.5$ & $41.3 \pm 5.9$ & $770 \pm 75$ & $770 \pm 201$ \\
\hline Mean gains & & & 615 & 580 \\
\hline
\end{tabular}

Pigs were fed ad libitum but feed consumption was recorded daily and on days 14, 35 and 49 the feed consumption was determined for the appropriate period. There were no significant differences in feed intake between groups, but average daily gains were better and feed conversion was $12 \%$ higher in the experimental group (Table 3 ).

TABLE 3

Feed intake and feed conversion by pigs during the experiment

\begin{tabular}{ccccc}
\hline \multirow{2}{*}{ Groups } & \multicolumn{5}{c}{ Weeks } \\
\cline { 2 - 5 } & $1-2$ & $3-5$ & $6-7$ & mean \\
\hline FI - E, kg feed/day/pig & 0.84 & 1.3 & 1.6 & 1.27 \\
FI - C, kg feed/day/pig & 0.84 & 1.4 & 1.7 & 1.35 \\
FC - E, kg feed/kg gain & 2.21 & 1.9 & 2.05 & 2.06 \\
FC - C, kg feed/kg gain & 2.47 & 2.3 & 2.18 & 2.31 \\
\hline
\end{tabular}

FI - feed intake, $\mathrm{FC}$ - feed conversion 
The experimental piglets did not suffer from diarrhoea while those in the control group were affected between the $2^{\text {nd }}$ and $5^{\text {th }}$ week. In the $2^{\text {nd }}$ week three weanlings had scouring for three days, one pig for four days and one pig for one day, in the $3^{\text {rd }}$ week diarrhoea occurred in three pigs for three days and in two pigs for two days. In the $4^{\text {th }}$ and the $5^{\text {th }}$ week we observed scouring in only one pigs for three days. That means that in the second week $22 \%$ of pigs had shown diarrhoea, i.e. $(14: 63) \times 100$, in the third week diarrhoea occurred in approximately $21 \%$, and in the fourth and fifth week approximately $5 \%$. The diarrhoea was only mild, faeces were pasty or liquid, they were never with mucus or blood.

The values of immunological indices (IMA a MI), reflecting the metabolic activity of phagocytes (INT) and polyclonal activation of lymphocytes (LMIA), showed no significant differences between the experimental and control groups of pigs and also within groups during the experiment (Table 4).

TABLE 4

Index of metabolic activity of phagocytes in the peripheral blood of pigs (IMA) and migration index of leukocytes in the peripheral blood of pigs (MI)

\begin{tabular}{lccc}
\hline Groups & Day 0 & Day 28 & Day 49 \\
\hline E - IMA & $2.71 \pm 0.31$ & $2.66 \pm 0.27$ & $2.81 \pm 0.17$ \\
C - IMA & $2.75 \pm 0.32$ & $2.53 \pm 0.31$ & $2.65 \pm 0.25$ \\
E - MI & $0.74 \pm 0.07$ & $0.71 \pm 0.08$ & $0.69 \pm 0.13$ \\
C - MI & $0.72 \pm 0.07$ & $0.73 \pm 0.10$ & $0.71 \pm 0.12$ \\
\hline
\end{tabular}

\section{DISCUSSION}

The last weighing showed that the mean weight of pigs from the experimental group was significantly higher than that in the control. Although the supply of nutrients and environmental factors has a great influence on the performance of pigs (Wenk, 1998), probiotics also seem to have an effect under good conditions and high daily weight gains. We know that both of the bacteria that are contained in the preparation used produce different enzymes, and they could increase the digestibility of the mixed ration in our trial.

Ahrens et al. (1992) conducted an experiment on weanlings and observed that supplementation of their rations with BioPlus $2 \mathrm{~B}$, at a dose of $1.2 \times 10^{6} / \mathrm{g}$ feed, resulted in significantly higher digestion of proteins in the small intestine of experimental pigs (76\%) in comparison with that in the control (68\%).

The effect of the probiotic strain Bacillus cereus var. toyoi on enterobacterial growth and selected metabolic parameters in pigs before and shortly after weaning was studied by Jadamus et al. (2002). They noticed that growth capacities of enterobacteria in digesta samples were significantly reduced. An antagonistic 
effect against enterotoxic, diarrhoea-causing Escherichia coli of Bacillus licheniformis in the preparation LSP 122 (Alpharma) was described by Kyriakis et al. (1999). The preparation was administered at concentrations of $10^{6}$ and $10^{7}$ spores/g feed and resulted in a significant decrease in the incidence of diarrhoea in experimental groups. Subsequently, the authors recorded significantly increased weight gains in experimental groups compared with the control, with the group supplemented with $10^{7}$ Bacillus licheniformis showing significantly higher gains even compared with the group supplemented with a lower dose of the probiotic. Diarrhoea also occurred in our experiment, however, only in control piglets in weeks 2-5 of the experiment, suggesting a protective effect of the preparation.

Spores of Bacillus subtilis germinate in the digestive tract (Casula and Cutting, 2002). Because the vegetative forms are sensitive to bile salts one may assume their subsequent sporulation or lysis. It is possible that the spores themselves exert a probiotic effect by acting as stimulators and increasing local cell-mediated immunity (Caruso et al., 1993). However, our experiment did not show significant differences in either phagocytic activity or polyclonal activation of lymphocytes isolated from the peripheral blood of pigs.

The results of our experiment indicate that probiotics based on representatives of the genus Bacillus can fully replace the antibiotics used as growth stimulators.

\section{REFERENCES}

Ahrens F., Schmitz M., Warlies B., 1992. Mikrobieller Zusatzstoff in der Ferkelfütterung. Kraftfutter $75,418-420$

Bendixen G., Bentzen K., Clausen J.E., 1976. Inhibition of human leucocyte migration. In: J.B. Natvig, P. Permann, H. Wigzel (Editors). Lymphocytes. Isolation, Fractionation and Characterization. Scand. J. Immunol., Suppl. 5, 244-267

Caruso A., Flamminio G., Folghera S., Peroni L., Foresti I., Balsari A., Turano A., 1993. Expression of activation markers on peripheral-blood lymphocytes following oral administration of Bacillus subtilis spores. Int. J. Immunopharmacol. 15, 87-92

Casula G., Cutting S.M., 2002. Bacillus probiotics: Spore germination in the gastrointestinal tract. Appl. Environ. Microbiol. 68, 2344-2352

Korim P., Bugarský A., Juriš P., Hadbavný M., Korimová J., 2003. Protection of experimental animals (in Slovak). Slov. Vet. Čas. 28 (1), 10-12

Jadamus A., Vahjen W., Schafer K., Simon O., 2002. Influence of the probiotic strain Bacillus cereus var. toyoi on the development of enterobacterial growth and on selected parameters of bacterial metabolism in digesta samples of piglets. J. Anim. Physiol. Anim. Nutr. 86, 42-54

Kyriakis S.C., Tsiloyiannis V.K., Vlemmas J., Sarris K., Tsinas A.C., Alexopoulos C., Jansegers L., 1999. The effect of probiotic LSP 122 on the control of post-weaning diarrhoea syndrome of piglets. Res. Vet. Sci. 67, 223-228

La Ragione R.M., Casua G., Cutting S.M., Woodward M.J., 2001. Bacillus subtilis spores competitively exclude E. coli 078:K80 in poultry. Vet. Microbiol. 79, 133-142 
Lokaj V., Oburkova P., 1975. Determination of the tetrazolium-reductase activity of leukocytes. Imunol. Zprav. 6, 42-44

Wenk C., 1998. Environmental effects on nutrient and energy metabolism in pigs. Arch. Tierernähr. $51,211-224$

\section{STRESZCZENIE}

\section{Probiotyki jako alternatywa dla antybiotyków w żywieniu świń}

Celem badań była ocena wpływu probiotycznego preparatu BioPlus 2B, zawierającego Bacillus licheniformis i Bacillus subtilis, na dzienne przyrosty, wykorzystanie paszy, ogólny stan zdrowia oraz fagocytozę i mitogenną stymulację limfocytów u świń. Podawanie probiotyków istotnie zwiększyło masę ciała, w mniejszym stopniu średnie dzienne przyrosty (6\%) i wykorzystanie paszy (12\%) świń grupy doświadczalnej, a także zapobiegało również występowaniu biegunki.

Otrzymane wyniki wskazują, że probiotyki zawierając w swym składzie bakterie $\mathrm{z}$ gatunku Bacillus mogą zastapić antybiotyki stosowane jako stymulatory wzrostu. 